\title{
PENGARUH MODEL PEMBELAJARAN INKUIRI TERBIMBING TERHADAP HASIL BELAJAR
}

\author{
Endang Lovisia \\ Program Studi Pendidikan Fisika ,STKIP PGRI Lubuklinggau \\ lovisiae@gmail.com \\ Submit, 06-09-2018 Accepted, 25-12-2018 Publish, 27-12-2018
}

\begin{abstract}
: the research aims at finding out the significance influence of guided inquiry on students physic achievement. It was an experiment research by group comparison. The population was all of the tenth grade students of SMA Negeri 6 Lubuklinggau. The samples was collected by cluster random sampling with grade X1 as experiment class treated with guided inquiry and X2 as control class treated with lecturing method. Technique for collecting data was through test analysis. Based on the posttest result with level of confidence 5\% it was find out that tobtained $=2,61$ and ttabel $=2,02$ because tobtained $>$ ttabel. Therefore, it can be concluded that there was a significant effect of guided inquiry model on Student physic achievement at the tenth grade of SMAN 6 Lubuklinggau.
\end{abstract}

Keywords : Physic, Students' achievement, Guided Inquiry

\begin{abstract}
Abstrak: tujuan penelitian ini adalah untuk mengetahui pengaruh yang signifikan model pembelajaran inkuiri terbimbing terhadap hasil belajar fisika Siswa. Jenis penelitian adalah penelitian eksperimen murni yang dilakukan dengan adanya kelompok pembanding. Populasi dalam penelitian ini adalah seluruh siswa kelas XI SMA Negeri 6 Lubuklinggau. Sampel diambil secara acak dengan cara pengundian, sehingga didapat kelas $X_{1}$ sebagai kelas eksperimen diberikan pembelajaran Inkuiri terbimbing dan $X_{2}$ sebagai kelas kontrol diberikan pembelajaran dengan metode caramah. Teknik pengumpulan data menggunakan teknik tes. Berdasarkan hasil analisis data post-test dengan taraf kepercayaan $5 \%$ didapat $t_{\text {hitung }}=2,61$ dan $t_{\text {tabel }}=2,02$ karena $_{t_{\text {hitung }}}>t_{\text {tabel }}$, maka dapat disimpulkan bahwa ada pengaruh yang signifikan model pembelajaran inkuiri terbimbing terhadap hasil belajar Fisika Siswa Kelas X SMAN 6 Lubuklinggau.
\end{abstract}

Kata Kunci : Fisika, Hasil Belajar, Inkuiri Terbimbing.

\section{PENDAHULUAN}

Pendidikan merupakan salah satu bagian terpenting dalam kehidupan manusia, karena dengan pendidikan akan menentukan peradaban manusia pada masa yang akan datang. Pendidikan mempunyai peranan penting dalam membentuk karakter, perkembangan ilmu dan mental anak yang nantinya akan menjadi manusia dewasa yang berinteraksi damn melakukan banyak hal terhadap lingkungannya baik secara individu maupun sebagai makhluk sosial.

Dalam hal ini guru berperan penting untuk membimbing dan mengarahkan potensi ang dimiliki siswa agar menjadi lebih baik dalam menyalurkan porensi yang dimiliki. Dalam upaa meningkatkan mutu dan kualitas pendidikan peran guru sangatlah penting. Guru mempunyai taggung jawab atas terselenggaranya proses belajar mengajar dan menciptakan suasana belajar yang nyaman dan baik untuk guru maupun muridnya.

Keberhasilan proses kegiatan belajar mengajar pada pembelajaran fisika dapat diukur dari keberhasilan siswa yang dapat mengikuti kegiatan pembelajaran tersebut.

Guru berharap pada proses pembelajaran di kelas siswa dapat menyerap materi pelajaran dengan baik, hal ini ditandai dengan hasil belajar siswa. Untuk mendapatkan hasil belajar yang diharapkan, maka harus ditunjang oleh bahan pelajaran yang bermutu, model pembelajaran, sistem evaluasi, sarana penunjang dan sistem administrasi yang 
dapat memberikan kontribusi maksimal pada proses belajar. Model pembelajaran merupakan suatu perencanaan pelaksanaan pembelajaran di kelas yang menjadi pedoman dalam pelaksanaan pembelajaran untuk mencapai tujuan pembelajaran

Berdasarkan hasil wawancara yang dilakukan peneliti pada guru mata pelajaran fisika beliau mengatakan bahwa hasil belajar di kelas XI masih tergolong rendah. Hal ini dapat dilihat dari nilai semester ganjil pada tahun pelajaran 2017/2018 sebagian besar siswa belum dapat mencapai nilai KKM 70. Kenyataan ini menunjukkan masih rendahnya pemahaman siswa terhadap materi pelajaran fisika dan kegiatan pembelajaran lebih cenderung menggunakan metode ceramah yang berpusat pada guru tanpa adanya peran aktif siswa.

Berdasarkan uraian di atas maka penulis tertarik untuk mengadakan penelitian dengan judul "Pengaruh Model Pembelajaran Inkuiri Terbimbing Terhadap Hasil Belajar Fisika Siswa Kelas XI SMAN 6 Lubuklinggau

\section{LANDASAN TEORI \\ Tinjauan Tentang Belajar}

Menurut Slameto (2010) Belajar adalah suatu proses usaha yang dilakukan oleh seseorang untuk memperoleh suatu perubahan yang baru sebagai hasil pengalamanya sendiri dalam interaksi dengan lingkungannya. Belajar sebagai suatu proses adaptasi atau penyesuaian tingkah laku yang berlangsung secara progresif. Sedangkan menurut (Hakim dalam Trianto, 2007) belajar adalah suatu proses perubahan di dalam kepribadian manusisa, dan perubahan tersebut ditampakkan dalam bentk peningkatan kualitas dan kuantitas tingkah laku seperti peningkatan kecakapan, pengetahuan, sikap, kebiasaan, pemahaman, keterampilan daya, fikir, dan lain-lain kemampuanya. Berdasarkan beberapa pendapatr diatas, maka dapat disimpulkan bahwa belajar adalah suatu usaha sadar yang dilakukan oleh individu dalam perubahan tingkah laku baik melalui latihan dan pengalaman yang menyangkut aspek-aspek kognitif, afektif dan psikomotorik untuk memperoleh tujuan tertentu.

\section{Tinjauan Tentang Hasil Belajar}

Menurut (Romiszowski dalam Trianto (2010) hasil belajar sebagai keluaran dari suatu sistem pemrosesan berbagai masukan yang berupa informasi. Berdasarkan pengertian hasil belajar yang telah diuraikan maka dapat disimpulkan bahwa hasil belajar adalah pencapaian bentuk perubahan perilaku yang cenderung menetap dari ranah kognitif afektif, dan psikomotoris dari proses belajar yang dilakukan dalam waktu tertentu.

\section{Pengertian Model Pembelajaran}

Menurut Trianto (2007) model pembelajaran adalah suatu perencanaan atau suatu pola yang digunakan sebagai pedoman dalam merencanakan pembelajaran di kelas atau pembelajaran dalam tutorial. Sedangkan Menurut Joyce (dalam Trianto 2007) model pembelajaran adalah suatu perencanaan atau suatu pola yang di pergunakan sebagai upaya dalam merencanakan pembelajaran di kelas atau pembelajaran tutorial dan untuk menentukan perangkat- perangkat pembelajaran seperti buku-buku, film komputer, kurikuler dan lain-lain.

Menurut Arends (dalam Trianto 2007) model pembelajaran adalah mengacu pada pendekatan pembelajaran yang akan digunakan, termasuk di dalamnya tujuan-tujuan pengajaran, tahap-tahap dalam kegiatan pembelajaran, lingkungan pembelajaran dan pengelolahan kelas. Sedangkan Menurut Trianto (2007) Model pembelajaran adalah suatu perencanaan atau pola yang dapat kita gunakan untuk 
mendesain pola-pola mengajar secara tatap muka di dalam kelas atau mengatur tutorial, dan untuk menentukan material/perangkat pembelajaran termasuk di dalamnya buku-buku, filmfilm, tipe-tipe, program-program media komputer, dan kurikulum (sebagai kursus untuk belajar).

\section{Model Pembelajaran Inkuiri Terbimbing}

Menurut (Gulo dalam Suyatno, 2009) pembelajaran Inkuiri terbimbing tidak hanya mengembangkan kemampuan intelektual tetapi seluruh potensi yang ada termasuk Pengembangan emosinoal dan keterampilan berpikir sementara. Menurut (Suparno dalam Suyatno, 2009) Inkuiri terbimbing adalah Inkuiri yang banyak mengarahkan dan memberikan petunjuk baik lewat prosedur yang lengkap dan pertanyaan- pertanyaan pengarahkan selama proses Inkuiri. Guru banyak memberikan pertanyaan di selasela proses, sehingga kesimpulan lebih cepat dan mudah diambil.

Menurut (Roestiyah dalam Suprijono, 2010) Inkuiri Terbimbing adalah model pembelajaran Inkuiri yang dalam pelaksanaannya guru menyediakan bimbingan atau pertunjuk yang cukup luas kepada siswa. Menurut (Kunandar dalam Suprijono, 2010) pembelajaran inkuiri terbimbing adalah mendorong siswa untuk belajar melalui keterlibatan aktif mereka sendiri dengan konsep-konsep dan prinsipprinsip, dan guru mendorong siswa untuk memilki pengalaman dan melakukan percobaan yang memungkinkan siswa menemukan prinsip-prinsip untuk diri mereka sendiri.

Berdasarkan beberapa pendapat tersebut, dapat disimpulkan bahwa model pembelajaran Inkuiri Terbimbing merupakan suatu model yang menuntun siswa dalam mengembangkan kemampuan berpikir dan menekankan sikap ilmiah

Menurut (Trianto dalam Suprijon, 2010), sintak model pembelajaran Inkuiri Terbimbing sebagai berikut:

1. Menyajikan pertanyaan atau masalah Membimbing siswa mengidentifikasi masalah, kemudian dituliskan di papan tulis. Guru membagi siswa dalam kelompok.

2. Merumuskan hipotesis

Guru memberikan kesempatan pada siswa untuk curahkan pendapat dalam membentuk hipotesis. Guru membimbing siswa dalam menentukan hipotesis yang relevan dengan permasalah dan memprioritaskan mana yang menjadi prioritas penyelidikan

3. Merancang percobaan

Guru memberikan kesempatan pada siswa untuk menentukan langkah-langkah yang sesuai dengan hipotesis yang akan dilakukan. Guru membimbing siswa mengurutkan langkah-langka percobaan.

4. Melakukan percobaaan untuk memperoleh informasi.

Guru membimbing siswa dalam mendapatkan informasi melalui percobaan

5. Mengumpulkan dan menganalisis data. Guru memberi kesempatan pada setiap kelompok untuk menyampaikan hasil pengolahan data yang terkumpul

6. Membuat kesimpulan.

Guru membimbing siswa dalam membuat kesimpulan.

Menurut Trianto (2007) langkah langkah model pembelajaran Inkuiri terbimbing adalah sebagai berikut:

1. Menyajikan pertanyaan atau permasalahan meliputi kegiatan menggali pengetahuan awal siswa melalui demonstrasi, mendorong dan merangsang siswa untuk mengemukan pendapat kepada kelompoknya.

2. Membuat hipotesis meliputi kegiatkan mengajukan jawaban 
sementara tentang masalah dan diarahkan dalam menentukan hipotesis yang relevan dengan permasalahan dan memprioritaskan hipotesis man yang menjadi prioritas penyelidikan.

3. Merancang percobaan sesuai langkah-langkah yang ada dan mempelajari petunjuk eksperimen,melakukan percobaan untuk memperoleh informasi meliputi kegiatan melakukan percobaan dan mendapat informasi melalui percobaan.

4. Mengumpulkan data dan menganalisis data meliputi kegiatan mencari dan mengumpulkan data sebanyakbanyaknya dan menganalisis data yang sudah dikumpulkan untuk dapat dibuktikan hipotesis apakah benar atau tidak.

5. Menyimpulkan data meliputi kegiatan menyimpulkan data yang telah dikelompokkan dan dianalisis dan diambil kesimpulan kemudian dicocokkan dengan hipotesis.

Berdasarkan beberapa pendapat di atas maka dapat disimpulkan bahwa langkah-langkah pembelajaran inkuiri terbimbing adalah sebagai berikut :

1. Siswa diberikan permasalahan.

2. Siswa mengamati pada percobaan yang akan dilakukan.

3. Siswa menyajikan hasil dalam bentuk tulisan atau laporan.

4. Siswa mempresentasikan hasil percobaan di depan kelas.

5. Siswa membuat kesimpulan.

\section{METODE PENELITIAN Rancangan Penelitian}

Menurut (Arikunto, 2010) metode penelitian adalah cara yang digunakan oleh peneliti dalam mengumpulkan data penelitiannya. Jenis penelitian yang digunakan dalam penelitian ini adalah penelitian kuantitatif dengan metode eksperimen. Pada penelitian ini menggunakan design Pretest-posttest Control Group Design atau desain kelompok kontrol eksperiman. Desain penelitian dapat ditunjukkan pada tabel 1

Tabel 1. Pretest-posttest Control Group Design

\begin{tabular}{cccc}
\hline Group & Pretes & Perlakuan & Postes \\
\hline Eksperimen & $\mathrm{O}_{1}$ & $\mathrm{X}$ & $\mathrm{O}_{2}$ \\
Kontrol & $\mathrm{O}_{1}$ & - & $\mathrm{O}_{2}$ \\
\hline
\end{tabular}

Menurut (Arikunto, 2010) bahwa variabel penelitian adalah objek penelitian, atau apa yang menjadi titik perhatian penelitian. Dalam penelitian ini yang menjadi variable bebas adalah model pembelajaran Inkuiri Terbimbing sedangkan variabel terikat adalah hasil belajar fisika siswa

\section{Populasi dan Sampel \\ Populasi Penelitian}

"Populasi adalah keseluruhan subjek penelitian" (Arikunto, 2010). Sedangkan menurut (Mulyatiningsih, 2013) populasi adalah sekumpulan subjek yang akan diteliti, jadi dapat disimpulkan bahwa populasi adalah sekumpulan keseluruhan subjek ang akan diteliti

Adapun yang menjadi populasi dalam penelitian ini adalah seluruh siswa kelas X SMA Negeri 6 Lubuklinggau yang terdiri dari 8 kelas, dengan rincian dapat dilihat tabel 2.

Tabel 2 Populasi Penelitian

\begin{tabular}{ccccc}
\hline No & Kelas & $\begin{array}{c}\text { Laki- } \\
\text { Laki }\end{array}$ & $\begin{array}{c}\text { Perem- } \\
\text { puan }\end{array}$ & $\begin{array}{c}\text { Jum- } \\
\text { lah }\end{array}$ \\
\hline 1. & X 1 & 13 & 9 & 22 \\
\hline 2. & X 2 & 12 & 9 & 21 \\
3. & X 3 & 14 & 9 & 23 \\
4. & X 4 & 13 & 9 & 22 \\
\multicolumn{2}{r}{ Jumlah } & $\mathbf{5 2}$ & 36 & 88 \\
\hline
\end{tabular}

\section{Sampel Penelitian}

Sampel adalah sebagian atau wakil populasi yang diteliti (Arikunto, 2010). Dalam penelitian ini sampel yang diambil yaitu dua kelas yang diambil secara acak dengan teknik simple random sampling (pengundian). Cara demikian dilakukan apabila anggota populasi dianggap homogen (Sugiyono, 2011). Sampel yang 
digunakan dalam penelitian ini adalah siswa kelas X.1 sebagai kelas eksperimen yang berjumlah 22 siswa dan siswa kelas X.2 sebagai kelas kontrol yang berjumlah 21 siswa.

\section{Teknik Pengumpulan Data}

Teknik pengumpulan data yang digunakan dalam penelitian ini adalah teknik tes. Tes adalah serentetan pertanyaan atau latihan serta alat lain yang digunakan untuk mengukur keterampilan, pengetahuan inteligensi, kemampuan atau bakat yang dimiliki oleh individu atau kelompok (Arikunto, 2010).

Tes digunakan untuk mengumpulkan data tentang kemampuan menyelesaikan soal materi setelah diberi perlakuan model pembelajaran Inkuiri Terbimbing. Tes dilakukan sebanyak dua kali yaitu pretes dan postes pada kelas eksperimen dan kelas kontro. Pretes diberikan untuk melihat kemampuan awal siswa dan postes diberikan untuk memperoleh data tentang hasil belajar siswa setelah diberi perlakuan model pembelajaran Inkuiri Terbimbing. Tes yang diberikan berbentuk soal essay

\section{Teknik Analisis Data}

Teknik analisis data dalam penelitian ini adalah teknik kuantitatif. Setelah data terkumpul dari hasil pengumpulan data, maka kegiatan selanjutnya adalah melakukan analisis data tersebut. Teknik analisis data yang digunakan dalam penelitian adalah menggunakan cara statistik.

\section{Menentukan Rata-rata dan Simpangan Baku}

Menentukan skor rata-rata dan simpangan baku pada tes awal dan tes akhir untuk mengetahui hasil belajar pada kelas eksperimen semu dengan rumus:

$$
\bar{x}=\frac{\sum f i . x_{i}}{f_{1}}
$$

Keterangan: $\bar{x}$ : Nilai rata-rata sampel

$f_{i}:$ Frekuensi

$X_{i}$ : Titik tengah nilai tes

$$
S=\sqrt{\frac{\sum f_{i}\left(x_{i-} \bar{x}\right)^{2}}{n-1}}
$$

Keterangan:

$s:$ Simpangan baku

$\bar{x}$ : Nilai rata-rata sampel

$x_{i}$ : Titik tengah nilai $\mathrm{X}$

$n$ : Jumlah sampel keseluruhan

\section{Uji Normalitas}

Uji normalitas menggunakan rumus chi kuadrat yang bertujuan untuk menguji kesesuaian data dalam sebaran distribusi normal. Menurut (Sugiyono: 2010) uji normalitas bertujuan untuk melihat apakah kedua kelompok data, populasi berdistribusi normal atau tidak. Perhitungan uji normalitas ini menggunakan rumus Chi-kuadrat $\left(\chi^{2}\right)$

$$
\chi^{2}=\sum \frac{\left(f_{0}-f_{e}\right)^{2}}{f_{e}}
$$

Keterangan:

$\chi^{2}=$ harga Chi kuadrat yang dicari

$f_{0}=$ Frekuensi hasil observasi

$f_{e}=$ Frekuensi yang diharapkan

Selanjutnya, $\chi_{\text {hitung dibandingkan }}^{2}$ dengan $\chi_{\text {tabel }}^{2}$ dengan derajat kebebasan $(d k)=n-1 . \quad$ Dimana $n$ adalah banyaknya kelas interval data dengan signifikan $5 \%$. Jika $\chi_{\text {hitung }}^{2}<\chi_{\text {tabel }}^{2}$, maka distribusi data dinyatakan normal. Jika $\chi_{\text {hitung }}^{2} \geq \chi_{\text {tabel }}^{2}$, maka dapat dinyatakan bahwa data tidak berdistribusi normal (Arikunto, 2010).

\section{Uji Homogenitas}

Menurut (Sudjana, 2005) uji homogenitas varians antara kelompok eksperimen dan kelompok kontrol dimaksudkan untuk mengetahui keadaan varians antara kedua kelompok, sama atau 
berbeda. Adapun rumus yang digunakan adalah

$$
F=\frac{S_{1}^{2}}{S_{2}^{2}}
$$

Keterangan:

$S_{1}^{2}=$ Varians terbesar

$S_{2}^{2}=$ Varians terkecil

Dengan kriteria pengujiannya adalah jika $\mathrm{F}$ hitung $<\mathrm{F}$ tabel maka kedua varians kelompok data tersebut adalah homogen dan jika $\mathrm{F}$ hitung $>\mathrm{F}$ tabel maka varians kelompok tidak homogen.

\section{Uji Kesamaan Dua rata-rata}

Uji kesamaan dua rata-rata ini digunakan untuk menguji kesamaan antara dua rata-rata, dalam hal ini antara data kelompok eksperimen dan data kelompok kontrol. Menurut (Sudjana, 2002) jika kedua data berdistribusi normal dan homogen, maka uji statistik yang digunakan adalah uji t.

$$
t=\frac{\overline{x_{1}}-\overline{x_{2}}}{s \sqrt{\frac{1}{n_{1}}+\frac{1}{n_{2}}}}
$$

Dengan:

$s^{2}=\frac{\left(n_{1}-1\right) s_{1}^{2}+\left(n_{2}-1\right) s_{2}^{2}}{n_{1}+n_{2}-2}$

\section{Keterangan:}

$t=$ perbedaan rata-rata kedua sampel

$\overline{x_{1}}=$ nilai rata-rata kel.eksperimen

$\overline{x_{2}}=$ nilai rata-rata kelompok kontrol

$n_{1}=$ banyak sampel kel.eksperimen

$n_{2}=$ banyak sampel kelompok kontrol

$s_{1}^{2}=$ varians kelompok eksperimen

$s_{2}^{2}=$ varians kelompok kontrol

$s^{2}=$ varians gabungan

$\mathrm{H}_{0}$ diterima jika $\mathrm{t}_{\text {hitung }}<\mathrm{t}_{\text {tabel }}$ didapat dari $\mathrm{t}$ dengan $(\alpha=0,05)$, $\mathrm{dk}=$ $\left(\mathrm{n}_{1}+\mathrm{n}_{2}-2\right)$. Apabila kedua kelompok data berdistribusi normal dan varians tidak homogen, maka digunakan statistik t' (Sudjana:2005)

$$
t^{\prime}=\frac{\overline{x_{1}}-\overline{x_{2}}}{\sqrt{\frac{s_{1}^{2}}{n_{1}}+\frac{s_{2}^{2}}{n_{2}}}}
$$

Kriteria pengujiannya adalah terima hipotesis $\mathrm{H}_{0}$ jika:

$$
-\frac{w_{1} t_{1}+w_{2} t_{2}}{w_{1}+w_{2}}<t^{\prime}<\frac{w_{1} t_{1}+w_{2} t_{2}}{w_{1}+w_{2}}
$$

Dengan:

$w_{1}=\frac{s_{1}^{2}}{n_{1}}$

$w_{2}=\frac{s_{2}^{2}}{n_{2}}$

$t_{1}=t_{(1-1 / 2 a),\left(n_{1}-1\right)}$

$t_{2}=t_{(1-1 / 2 a),\left(n_{2}-1\right)}$

\section{Pertanggung Jawaban Penelitian Uji Validitas}

Menurut (Arikunto, 2010) validitas adalah suatu ukuran yang menunjukkan tingkat-tingkat kevalidan atau kesahihan sesuatu instrumen.

Menurut (Suherman dan Sukjaya, 1990), interprestasi yang lebih rinci mengenai nilai $r_{x y}$ tersebut dibagi dalam kategori seperti tabel 3 berikut ini.

Tabel 3. Kategori Uji Validitas Butir Soal

\begin{tabular}{ll}
\hline \multicolumn{1}{c}{$\begin{array}{c}\text { Nilai Koefisien } \\
\text { Korelasi }\end{array}$} & \multicolumn{1}{c}{ Keterangan } \\
\hline$r_{x y} \leq 0,00$ & Tidak valid \\
$0,00<r_{x y} \leq 0,20$ & Validitas sangat rendah \\
$0,20<r_{x y} \leq 0,40$ & Validitas rendah \\
$0,40<r_{x y} \leq 0,60$ & Validitas sedang \\
$0,60<r_{x y} \leq 0,80$ & Validitas tinggi \\
$0,80<r_{x y} \leq 1,00$ & Validitas sangat tinggi \\
\hline
\end{tabular}

Untuk menentukan keberartian dari koefisien validitas digunakan uji-t dengan rumus sebagai berikut:

$$
t=r_{x y} \sqrt{\frac{n-2}{1-r_{x y}^{2}}}
$$

Keterangan:

$n$ = banyak data,

$r_{x y}=$ korelasi product momment,

$t=$ distribusi student.

Harga thitung diperoleh untuk taraf kesalahan 5\% uji satu pihak dengan $\mathrm{dk}=$ n-1. Jika thitung > ttabel, maka $H_{a}$ diterima dan $H_{0}$ ditolak dengan kata lain 
terdapat hubungan signifikan atau butir soal dikatakan valid.

\section{Uji Realibilitas}

Instrumen yang reliabel berarti instrumen yang bila digunakan beberapa kali untuk mengukur obyek yang sama, akan menghasilkan data yang sama (Sugiyono, 2011).

Rumus yang digunakan untuk mencari nilai koefisien bentuk uraian adalah dengan rumus Alpha $\left(r_{11}\right)$, yaitu sebagai berikut;

$$
r_{11}=\left(\frac{k}{k-1}\right)\left(1-\frac{\sum \sigma_{b}{ }^{2}}{\sigma_{t}{ }^{2}}\right)
$$

Keterangan :

$r_{11}:$ Reliabilitas instrumen

$\mathrm{K}$ : Banyaknya butir pertanyaan atau banyaknya soal

$\sum \sigma_{b}^{2}:$ Jumlah varians butir

$\sigma_{t}^{2} \quad$ : Varians total

Tabel 4. Kategori Uji Reliabilitas

\begin{tabular}{ll}
\hline $\begin{array}{c}\text { Nilai Reliabilitas } \\
\text { Instrumen }\end{array}$ & \multicolumn{1}{c}{ Keterangan } \\
\hline$r_{11} \leq 0,20$ & Reliabilitas sangat \\
$0,20<r_{11} \leq 0,40$ & rendah \\
$0,40<r_{11} \leq 0,60$ & Reliabilitas rendah \\
$0,60<r_{11} \leq 0,80$ & Reliabilitas sedang \\
$0,80<r_{11} \leq 1,00$ & Reliabilitas tinggi \\
& Reliabilitas sangat tinggi \\
\hline
\end{tabular}

\section{Daya Pembeda}

Daya pembeda sebuah butir soal adalah kemampuan butir soal itu untuk membedakan antara testi (siswa) yang pandai atau berkemampuan tinggi dengan siswa yang bodoh (Suherman dan Sukjaya, 1990). Untuk menentukan daya pembeda digunakan rumus :

Keterangan :

$$
D P=\frac{J B_{A-} J B_{B}}{J S_{A}}
$$

$D P \quad$ : Indeks daya pembeda

$J B_{A} \quad$ : Jumlah skor kelompok atas

$J B_{B} \quad$ : Jumlah skor kelompok bawah

$J S_{A} \quad$ : Jumlah skor ideal kelompok atas

Menurut Suherman dan Sukjaya (1990), klasifikasi interprestasi untuk daya pembeda dapat dilihat seperti tabel 5.
Tabel 5. Klasifikasi Daya Pembeda Butir Soal

\begin{tabular}{cc}
\hline $\begin{array}{c}\text { Indeks Daya } \\
\text { Pembeda }\end{array}$ & Keterangan \\
\hline$D P \leq 0,00$ & Sangat jelek \\
$0,00<D P \leq 0,20$ & Jelek \\
$0,20<D P \leq 0,40$ & Cukup \\
$0,40<D P \leq 0,70$ & Baik \\
$0,70<D P \leq 1,00$ & Sangat baik \\
\hline
\end{tabular}

\section{Tingkat Kesukaran}

Derajat kesukaran suatu butir soal dinyatakan dengan bilangan yang disebut Indeks Kesukaran (Difficulty Index). Bilangan tersebut adalah bilangan real pada interval 0,00 sampai dengan 1,00. Soal dengan indeks kesukaran mendekati 0,00 berarti butir soal tersebut terlalu sukar, sebaliknya soal dengan indeks kesukaran 1,00 berarti soal tersebut terlalu mudah (Suherman dan Sukjaya, 1990). Soal yang tingkat kesukarannya sedang, sebab bila tingkat kesukaran soal itu sedang maka dapat memberikan informasi mengenai perbedaan individual yang paling besar. Rumus untuk menghitung indeks kesukaran butir soal yaitu:

$$
I K=\frac{J B_{A}+J B_{B}}{J S_{A}+J S_{B}}
$$

Keterangan :

IK : Indeks Kesukaran

$J B_{A} \quad$ : Jumlah skor kelompok atas

$J B_{B} \quad$ : Jumlah skor kelompok bawah

$J S_{A} \quad$ : Jumlah skor ideal kelompok atas

$J S_{B} \quad$ : Jumlah skor ideal kelompok bawah

Tabel 6. Klasifikasi Indeks Kesukaran Butir Soal

\begin{tabular}{cc}
\hline Indeks Kesukaran & Keterangan \\
\hline$I K=0,00$ & Soal terlalu sukar \\
$0,00<I K \leq 0,30$ & Soal sukar \\
$0,30<I K \leq 0,70$ & Soal sedang \\
$0,70<I K<1,00$ & Soal mudah \\
$I K=1,00$ & Soal terlalu mudah \\
\hline
\end{tabular}

Berdasarkan analisis tes hasil uji coba tes instrumen, maka soal yang akan digunakan untuk tes adalah soal yang 
memenuhi syarat validitas, daya pembeda, dan tingkat kesukaran yang baik. Dari 10 soal yang diujikan, ada 5 soal yang dipakai dan 5 soal yang tidak dipakai sebagai instrumen dalam penelitian.

\section{HASIL DAN PEMBAHASAN Analisis Deskriptif data Penelitian}

Penelitian ini dilaksanakan di kelas XI SMA Negeri 6 Lubuklinggau dimulai dari tanggal 02 Oktober sampai 23 Nopember 2017 Jumlah seluruh siswa kelas XI jurusan MIPA yaitu sebanyak 88 siswa dari 4 kelas yang ada.

Berdasarkan empat kelas tersebut, hanya diambil dua kelas secara acak. Jumlah pertemuan tatap muka yang dilakukan adalah masing-masing empat kali pertemuan baik untuk kelas eksperimen maupun kelas kontrol dengan rincian satu kali pemberian pretes, dua kali proses pembelajaran dengan model pembelajaran Inkuiri Terbimbing untuk kelas eksperimen dan model pembelajaran konvensional untuk kelas kontrol dan satu kali pemberian postes baik untuk kelas eksperimen maupun kelas kontrol.

\section{Data Hasil Kemampuan Awal Siswa (pre-test).}

Pemberian pretes dilakukan pada pertemuan pertama. Pelaksanaan pretes ini berfungsi unruk mengetahui kemampuan awal tentang suatu materi dari masing-masing kelas, baik kelas eksperimen maupun kelas kontrol. Soal yang digunakan berbentuk essay yang terdiri dari 5 soal.

Tabel 7. Hasil Perhitungan Data Pretes

\begin{tabular}{lll}
\hline \multicolumn{1}{c}{ Nilai } & Eksperimen & Kontrol \\
\hline Minimal & 28 & 24 \\
Maksimal & 57 & 52 \\
Rata-rata & 37,95 & 36,95 \\
Simpangan baku & 7,01 & 7,00 \\
\hline
\end{tabular}

Berdasarkan tabel 7, secara deskriptif dapat disimpulkan bahwa kemampuan awal siswa pada pengetahuan awal sama-sama masih rendah dan tidak ada perbedaan yang berarti antara kelas eksperimen dan kelas kontrol ditinjau dari rata-rata nilainya.

\section{Data Kemampuan Akhir Siswa (post- test).}

Postes dilakukan untuk melihat hasil belajar siswa setelah mengikuti pembelajaran fisika dengan menggunakaan model pembelajaran Inkuiri Terbimbing. Postes ini dilakukan pada pertemuan terakhir baik untuk kelas eksperimen maupun kelas kontrol. Adapun hasil perhitungan postes dapat dilihat pada tabel berikut

Tabel 8. Hasil Perhitungan Data Postes

\begin{tabular}{lll}
\hline \multicolumn{1}{c}{ Nilai } & Eksperimen & Kontrol \\
\hline Minimal & 57 & 52 \\
Maksimal & 95 & 90 \\
Rata-rata & 76,55 & 68,67 \\
Simpangan baku & 9,79 & 10,02 \\
\hline
\end{tabular}

\section{Analisis Interferensial Data Penelitian}

Data penelitian yang diperoleh dari hasil postes akan digunakan untuk menguji hipotesis secara statistik. Adapun hipotesis dalam penelitian ini adalah "Ada pengaruh yang signifikan model pembelajaran Inkuiri Terbimbing terhadap hasil Belajar fisika siswa kelas XI SMAN 6 Lubuklingau”.

\section{Uji Normalitas}

Untuk mengetahui kenormalan data, digunakan uji normalitas data dengan uji kecocokan $\chi^{2}$ (chi-kuadrat). Berdasarkan ketentuan perhitungan statistik mengenai uji normalitas data dengan taraf kepercayaan $\alpha=0,05$, jika $\chi_{\text {hitung }}^{2}<\chi_{\text {tabel }}^{2}$ maka data berdistribusi normal. Perhitungan uji normalitas dapat dilihat pada tabel berikut

Tabel 9. Hasil Perhitungan Data Postes

\begin{tabular}{|c|c|c|c|c|}
\hline Nilai & Kelas & $\chi 2_{\text {hit }}$ & $\chi 2_{\text {tab }}$ & kesimpulan \\
\hline \multirow[t]{2}{*}{ Pretes } & $\mathrm{E}$ & 3,829 & 11,070 & Normal \\
\hline & K & 8,532 & 11,070 & Normal \\
\hline \multirow[t]{2}{*}{ Postes } & $\mathrm{E}$ & 6,148 & 11,070 & Normal \\
\hline & K & 1,918 & 11,070 & Normal \\
\hline
\end{tabular}


Dari tabel diatas dapat disimpulkan bahwa masing-masing kelas untuk data pretes maupun postes pada kelas eksperimen dan kelas kontrol berdistribusi normal.

\section{Uji Homogenitas}

Uji homogenitas untuk melihat kedua kelompok mempunyai varians yang homogen atau tidak. Adapun perhitungannya dapat dilihat pada tabel dibawah ini.

Tabel 10. Hasil Perhitungan Uji Homogenitas

\begin{tabular}{|c|c|c|c|c|}
\hline Varians & $\mathbf{F}_{\text {hit }}$ & dk & $F_{t a b}$ & kesimpulan \\
\hline Pretes & 1,00 & $20: 20$ & 2,12 & \\
\hline Postes & 1,05 & $20: 20$ & 2,12 & homogen \\
\hline
\end{tabular}

Jika $\mathrm{F}_{\text {hitung }}<\mathrm{F}_{\text {tabel }}$ maka dinyatakan bahwa varians kedua kelompok data adalah homogen. Berdasarkan tabel diatas diperoleh bahwa untuk varians skor pretes diperoleh $F_{\text {hitung }}=1,00$ dan varians skor postes diperoleh $\mathrm{F}_{\text {hitung }}=1,05$ dengan $\mathrm{dk}$ $=(20: 20)$ diperoleh ftabel $=2,12$. Maka $\mathrm{H}_{0}$ diterima sehingga data kedua varians tersebut homogen

\section{Uji Hipotesis}

Uji hipotesis daalm penelitian ini adalah menggunakan uji kesamaan dua rata-rata. Berdasarkan hasil uji normalitas dan uji homogenitas ang telah dilakukan, maka kedua kelas pada pretes dan postes berdistribusi normal dan homogen sehingga uji kesamaan dua rata-rata ang digunakan adalah uji-t.

Tabel 11. Hasil Perhitungan Uji kesamaan dua rata-rata

\begin{tabular}{lccl}
\hline \multicolumn{1}{c}{ Hasil tes } & $\mathbf{t}_{\text {hit }}$ & $\mathbf{F}_{\text {tab }}$ & kesimpulan \\
\hline Pretes & 0,47 & 2,02 & $\mathrm{H}_{0}$ diterima \\
Postes & 2,61 & 2,02 & $\mathrm{H}_{0}$ ditolak \\
\hline
\end{tabular}

Berdasarkan hasil pretes siswa dapat disimpulkan bahwa kemampuan awal siswa pada pengetahuan sama-sama masih rendah dan tidak ada perbedaan yang begitu besar antara kelas eksperimen dan kelas kontrol. Sedangkan hasil postes siswa, terdapat perbedaan kemampuan akhir anatara kelas eskperimen dan kelas kontrol hal ini berarti ada pengarug yang signifikan model pembelajaran Inkuiri terbimbing terhadap hasil belajar fisika siswa.

Pada kelas kontrol siswa diajarakan dengan model pembelajaran konvensional dengan metode ceramah sedangkan pada kelas eksperimen siswa diajarkan mengguanakan model pembelajaran Inkuiri Terbimbing.

Dalam model pembelajaran Inkuiri Terbimbing ini siswa dibagi menjadi kelompok-kelompok belajar. Tiap kelompok terdiri dari 3-4 orang siswa yang kemampuan akademiknya berbeda (heterogen) kemudian dibagikan Lembar Kerja Praktikum (LKP) untuk tiap kelompok.

Pada pertemuan pertama pelaksanaan model pembelajaran Inkuiri terbimbing di kelas eksperimen ini awalnya siswa mengalami kesulitan dan menemukan hambatan-hambatan, hal ini dikarenakan adanya perubahan teknik mengajar yang dirasakan oleh siswa sebagaai hal baru dan memerlukan penyesuaian. Ini terlihat sebagian siswa masih pasif pada saat melaksanakan percobaak praktikum.

Namun setelah dilaksanakan pembelajaran Inkuiri Terbimbing pada pertemuan kedua siswa mulai tertarik dan antusias dalam mengikuti pembelajaran. Hal ini ditandai dengan adanya kerja sama dalam kelompok dan rasa penyelidikan atau penemuan siswa terhadap permasalah menjadikan siswa lebih termotivasi menggali pengetahuannya sendiri dengan bimbingan dari guru. Adanya kerja sama dalam kelompok membuat siswa dapat saling bertukar pikiran, serta siswa yang pandai dapat memberikan informasi kepada siswa yang lemah pengetahuannya. Hal inilah yang menjadikan siswa merasa termotivasi dan hasil belajar siswapun meningkat.

Berdasarkan analisis secara statistik terbukti bahwa ada pengaruh yang signifikan model pembelajaran Inkuiri 
Terbimbing terhadap hasil belajar fisika diswa pada kelas XI SMAN 6 Lubuklinggau. Dengan demikian hipotesis penelitian yang diajukan dalam penelitian ini dapat diterima kebenarannya.

\section{SIMPULAN}

Berdasarkan hasil penelitian dapat disimpulkan bahwa ada pengaruh yang signifikan model pembelajaran Inkuiri Terbimbing terhadap hasil belajar fisika siswa kelas XI SMAN 6 Lubuklinggau. Hal ini ditunjukkan dengan hasil analisis uji-t dengan $t_{\text {hitung }}(2,61)>t_{\text {tabel }}(2,02)$ dengan $\alpha=0,05$. Nilai rata-rata tes akhir hasil belajar fisika siswa pada kelas eksperimen sebesar 76,55 dan pada kelas kontrol bsebesar 68,67

\section{DAFTAR PUSTAKA}

Arikunto, Suharsimi. (2010). Prosedur Penelitian Suatu Pendekatan Praktik. Jakarta: Rineka Cipta

Mulyatiningsih, Endang. (2013). Metode Penelitian Terapan Bidang Pendidikan. Bandung: Alfabeta

Slameto. (2010). Belajar dan Faktorfaktor Yang Mempengaruhinya. Jakarta: Rineka Cipta

Sudjana. (2005). Metoda Statistik. Bandung: Tarsito.

Sugiyono. (2011). Statistika untuk Penelitian. Bandung: Alfabeta

Suherman dan Sukjaya. (1990). Petunjuk Praktis untuk Melaksanakan Evaluasi Pendidikan Matematika. Bandung : Wijayakusumah

Suprijono. (2010). Cooperative Learning Teori dan Aplikasi Paikem.Yogyakarta Pustaka Belajar
Suyatno. (2009). Menjelajah Pembelajaran Inovatif. Surabaya : Masmedia Buana Pustaka

Trianto. (2007). Model-model Pembelajaran Inovatif Berorientasi Konstruktivistik. Surabaya: Prestasi Pustaka Publisher

Trianto. (2010). Mendesain Model Pembelajaran Inovatif-Progresif. Jakarta : Prenada Media Group 